\title{
Social networks and financial outcomes
}

\author{
Raghavendra Rau \\ University of Cambridge
}

\begin{abstract}
Academic research on whether social networks influence financial outcomes is still undeveloped. The literature has typically focused on three major questions - whether social networks affect investor behavior, firm behavior, or intermediary behavior. Because the theoretical framework in finance is organized around an accepted set of paradigms, and because data on intermediaries and firms have been publicly available for a long time, the financial economics area has just started using big data in its analysis. This note describes the extant research in this area and outlines how the field is likely to evolve.
\end{abstract}

\section{Highlights}

- The major research questions for financial economists involve analysing investor behavior, firm behavior, or intermediary behavior

- Since firm data has been publicly available for a long time, most research on social networks in affecting financial outcomes does not use big data

- This is changing and future research, especially research on investor behavior, is likely to use big data analysis.

\section{Introduction}

Economists typically analyze either cross-sectional, time series, or panel data that fits in a spreadsheet or a statistical database. While these approaches are gradually being replaced by big data analyses in other disciplines (see Einav and Levin, 2014 for examples of econometric analyses using big data techniques), these approaches have not typically been used by financial economists who are interested in how social networks impact financial outcomes. The reason is because financial economists work with clearly defined theoretical priors. To test these priors does not always require extremely large datasets, which are more suited to situations where the model itself is uncertain. ${ }^{1}$

Financial economists are usually concerned with three major research questions: how do investors choose to invest (a portfolio choice problem), how firms direct these investments to

\footnotetext{
${ }^{1}$ Varian (2014) differentiates between big data analysis and regular economic analysis in noting that the sheer size of big datasets may require more powerful data manipulation tools. There may be more potential predictors than appropriate for estimation, so variable selection is necessary. Large datasets may also allow for more flexible relationships than simple linear models. Finally, machine learning techniques such as decision trees, support vector machines, neural nets, and deep learning, may allow for more effective ways to model complex relationships.
} 
investment opportunities (a firm investment decision), and how intermediaries manage to match the lenders (investors) with the firms (borrowers). The questions of interest in this note are whether social relationships influence investor behavior (the portfolio choice problem or other financial decisions), firm behavior (the investment decision or other firm policy decisions), or the matching process.

The papers surveyed in this note typically use unusual micro-level data on social networks to address these questions. Examples of these types of data discussed in this note include characteristics for an entire population from country administrative registers (typically Scandinavian countries), insider trading networks, and loan level data from microfinance institutions.

\section{Social networks and investor behavior}

The first type of financial outcome relates to whether social networks affect portfolio choices made by investors. In particular, papers in this stream examine how information diffuses through social networks. Among the earliest papers in this field, Hong, Kubik, and Stein (2004) argue that social investors find the market more attractive when more of their peers participate. They use data from the Health and Retirement Study administered by the Institute for Social Research at the University of Michigan. This survey, first conducted in 1992, surveys approximately 7,500 households who have a member born during the period 1931 through 1941, and asks whether people interact with their neighbors or attend church, a group that Hong, Kubik, and Stein call social households. They find that social households are substantially more likely to invest in the market than non-social households, controlling for wealth, race, education, and risk tolerance. Similarly, Ivković and Weisbenner (2007) study the relation between households' actual stock purchases and stock purchases made by their neighbors using a popular data set of common-stock investments in 35,673 U.S. households made through a large discount brokerage in the period from 1991 to 1996 . Till a few years ago, this dataset was largely the only dataset on actual portfolio choice by individuals in the United States. Ivković and Weisbenner (2007) attribute approximately $25-50 \%$ of the correlation between households' stock purchases and stock purchases made by their neighbors to word-of-mouth communication.

More recent papers have drawn on other datasets, both survey and direct. For example, Changwony, Campbell, and Tabner (2014) examine information diffusion through two channels 
of social interaction: frequency of talking to neighbors and involvement in social groups using survey data from around 14,000 individuals in 5,500 households covered by the British Household Panel Survey (BHPS). They find that weak ties (social group involvement) between individuals positively impacts overall stock market participation while strong ties (frequency of talking to neighbors) have no effect. Knüpfer, Rantapuska, and Sarvimäki (2017) use Finnish country population characteristics from Statistics Finland and the Finnish Tax Administration to show that workers who are adversely affected by the Finnish Great Depression in the 1990s, invest less in stock markets. The effects appear to travel through social networks: individuals whose neighbors and family members experienced adverse circumstances also avoid risky investments. Rau and Wardrop (2017) examine how local bias, the predisposition of investors to invest in local firms, is affected by the physical distances from other types of investors, specifically super-investors (investors who invest extremely large amounts in specific investments), in influencing investment in a novel financial instrument, micro-bonds directly issued by the firm to its investors without a financial intermediary involved. Physical distances to these investors appears as, if not more, important to investment than the physical distance to the firm. One issue with these papers is that they do not provide direct evidence of person-to-person communication among investors. Ahern (2017) provides some evidence of direct peer-to-peer communication, using a relatively small but novel hand-collected dataset to analyze the social relationships that underlie illegal insider trading networks. He shows that inside information flows through strong social ties based on family, friends, and geographic proximity. Inside traders earn striking returns of $35 \%$ over 21 days, with more central traders earning greater returns.

A second related question of concern to financial economists is whether the presence of social networks increases market efficiency, the speed with which information is incorporated into stock prices. Han and Yang (2013) develop a rational expectations equilibrium model to explore this question and show that when information is exogenous, social communication improves market efficiency. However, social communication also crowds out information production due to traders' incentives to "free ride" on their informed friends. Overall, social communication hurts market efficiency when information is endogenous. There is little empirical evidence on this issue. 
A third question relevant to this research topic is how the network positions of the first individuals in a society to receive information about a new product affect its eventual diffusion. To answer this question, Banerjee, Chandrasekhar, Duflo, and Jackson (2013) develop a model of information diffusion through a social network that discriminates between information passing (individuals must be aware of the product before they can adopt it, and they can learn from their friends) and endorsement (the decisions of informed individuals to adopt the product might be influenced by their friends' decisions), and apply it to the diffusion of microfinance loans, in a setting where the set of potentially first-informed individuals is known. They find that the centrality of the first-informed individuals in a village helps significantly in predicting eventual adoption.

A relatively unexplored issue in financial economics is whether firms can create peer influence and social contagion by designing viral features into their products and marketing campaigns. While there are no financial economics papers on this issue because financial data is usually highly confidential, a couple of marketing papers do use big data to analyze this question. Aral and Walker $(2011,2014)$ conduct randomized field experiments where they use viral messaging capabilities for 9,687 recruited users on Facebook.com to exchange messages with their 1.4 million friends. They find that viral features generate econometrically identifiable peer influence and social contagion effects, with passive-broadcast viral features in particular, proving most effective in increasing peer influence and social contagion. Physical interaction between friends, measured by co-appearance in photos, does not have an effect. Manski (1995) argues that self-selection bias makes it harder to draw inferences about the general population from a self-selected sample of recruited subjects. In addition, a generalizable analysis is limited to observations that are made without intrusion, since people's behavior may change when they know they are being observed.

To avoid the problem of self-selection and observation bias, Bapna and Umyarov (2015) use a randomized experiment that tests the existence of causal peer influence in the general population (3.8 million users) of the last.FM online social network. The experiment, which did not involve subject recruitment for experimentation, involved the researchers randomly selecting users from the group to receive premium subscription status. These users could not deny the gift or hide its status, ruling out any subject self-selection, impact of individual characteristics, or contextual (observed or unobserved) decisions that might confound the analysis. They find that 
peer influence causes more than a $60 \%$ increase in odds of buying the service due to the influence coming from an adopting friend. In addition, users with smaller numbers of friends experience stronger relative increase in their adoption likelihood due to influence from their peers compared to users with larger numbers of friends.

Researchers have also examined other financial choices by investors. For example, Miller (2015) examines how social networks affect a household's bankruptcy decision. Social networks can provide information about the required paperwork, recommend attorneys, reduce social stigma associated with bankruptcy, or increase awareness of its benefits. Using a sample from the Panel Study of Income Dynamics (PSID), she exploits county and racial variation in bankruptcy to identify network effects and examines whether being surrounded by others of the same race increases bankruptcy use more for those in racial groups with high filing rates. She finds a positive and significant coefficient on the interaction between availability of contacts potentially advising on bankruptcy and the bankruptcy filing rate of the investor's racial group.

\section{Social networks and firm behavior}

In this stream of research, financial economists typically ask if the presence of social networks affects firm policy. The dependent variables here usually consist of firm level data on firm policy, while the explanatory variables consist (mostly) of social connections between managers, board members, and financial intermediaries. As an example of connections between managers and financial intermediaries, Javakhadze, Ferris, and French (2016) construct a panel dataset of managerial social connections via education, employment and other social activities, using the BoardEx database provided by Management Diagnostics Limited. They find that managerial social capital, proxied by managerial social connections to financier firms, is positively associated with investment sensitivity to the Tobin's $Q$ of the firm, a measure of growth opportunities. The effect of social capital is stronger in a market characterized by weak legal protection of investors. Similarly, Engleberg, Gao, and Parsons (2012) show that when banks and firms are connected through interpersonal linkages - such as their respective management having attended college or previously worked together - interest rates are markedly reduced, comparable with single shifts in credit ratings. As an example of connections between board members leading to changes in firm policy, Chiu, Teoh, and Tian (2012) test whether earnings management behavior spreads between firms via shared directors. They find that a firm 
is more likely to manage earnings when it shares a common director with a firm that is currently managing earnings and is less likely to manage earnings when it shares a common director with a non-manipulator. Similarly, Cai, Dhaliwal, Kim and Pan (2014) examine whether board connections through shared directors influence firm disclosure policies and find that firms are more likely to stop providing quarterly earnings guidance if they share directors with previous guidance stoppers.

\section{Social networks and financial intermediary behavior}

Finally, financial economists typically examine if the presence of social networks affects the matching process between investors and firms. The dependent variables here usually consist of either investor level portfolio choices or firm behavior, while the explanatory variables consist (mostly) of social connections between either investors or managers and financial intermediaries. As an example, Cohen, Frazzini, and Malloy (2010) study how social networks affect analysts' ability to gather superior information about firms. They collect data on the educational background of sell-side analysts and senior corporate officers from online sources such as ZoomInfo, and show that analysts outperform by up to $6.60 \%$ per year on their stock recommendations when they have an educational link to the company.

\section{Future directions and conclusion}

Academic research on whether social networks influence financial outcomes is still in its infancy. The literature has typically focused on three major questions - whether social networks affect investor behavior, firm behavior, or intermediary behavior. The evidence on the latter two comes from large datasets that have been available on listed firms going back nearly a century. Because the theoretical framework in finance is organized around a broadly accepted set of paradigms, and because data on intermediaries and firms have been publicly available for so long, the financial economics area has typically not made much use of big data. The area of investor behavior appears likely to be the area that is most likely to use big data analysis to answer research questions. Among the most promising appears to be the analysis of transactionlevel data obtained from individual peer-to-peer crowdfunding platforms such as debt-, equity-, reward- or donation-based platforms. Examples of this type of research include Michels (2012), Zhang, and Liu (2012), Lin, Prabhala, and Viswanathan (2013), and Iyer, Khwaja, Luttmer, and Shue (2016), all use data from Prosper.com, a large peer-to-peer (P2P) lending website in the 
United States (US), Li and Martin (2016) and Mollick and Nanda (2016), use data from

Kickstarter, a reward-based platform in the US, while Bi, Liu, and Usman (2017) use data from a reward-based platform in China. These papers delve into micro-level questions such as whether individuals are better able to screen their peer's creditworthiness than formal credit scoring methodology. The Centre for Alternative Finance, hosted at the University of Cambridge is drawing on this type of data to analyze individual borrower and investor profiles for significant sections of the United Kingdom (UK) peer-to-peer universe, in association with the Financial Conduct Authority (FCA) in the UK. ${ }^{2}$ Understanding investor profiles is also likely to have an impact on future regulation in the UK.

Understanding how the legal regime of a country has an impact on the borrowing and lending behavior of individuals in the country is another likely target of future research. In the UK, for example, peer-to-peer equity issues do not have to be registered, unlike in the United States. It is plausible that the process of registration generates formal standardized information that investors can use to price securities. If so, it is equally plausible that registration or disclosure requirements will have an impact on the growth rate of markets in different countries. While no individual-level study has examined this question, Rau (2017) shows that the volume of crowdfunding at the country level is negatively related to the ease of setting up a formal business in the country, consistent with the hypothesis that because regulations form barriers to formal entry, platforms that surmount these barriers are treated as better quality by investors.

However, because there are significant legal and privacy concerns to using data that is identifiable to individuals or providers, some research questions are currently more difficult to answer than others. For example, it is likely to be relatively difficult to track individuals across platforms. Here too, there are promising avenues for future research. The Payments Services Directive 2 (PSD2), due to be implemented across the European Union in 2018, will force banks to share customer-account information with licensed financial services providers. With suitable anonymization, access to these datasets can allow academics to potentially analyze investor behavior in much greater detail.

\footnotetext{
${ }^{2}$ See Williams, A., 2016, FCA asks University of Cambridge to help it understand P2P, Financial Times, September 30, 2016 (available at https://www.ft.com/content/d5635e3a-8642-11e6-8897-2359a58ac7a5). The FCA issued a press release describing the feedback to the post-implementation review of the FCA crowdfunding rules (available at https://www.fca.org.uk/publication/feedback/fs16-13.pdf). Section 5.8 discusses the collaboration with the CCAF.
} 


\section{Conflict of interest statement}

Nothing declared. 


\section{References}

Ahern, KR: Information networks: Evidence from illegal insider trading tips. Journal of Financial Economics. 2017, forthcoming.

* Aral, S Walker, D: Creating social contagion through viral product design: A randomized trial of peer influence in networks. Management Science 2011, 57: 1623-1639.

One of the first studies using a randomized control trial on Facebook to study whether firms can create peer influence.

Aral, S Walker, D: Tie strength, embeddedness, and social influence: A large-scale networked experiment. Management Science 2014, 60: 1352-1370.

* Banerjee, AC Duflo, E Jackson, MO: The diffusion of microfinance. Science 2013, 341.

Develops a network model to show how the network positions of the first individuals in a society to receive information about a new product affect its eventual diffusion

** Bapna, R Umyarov, A: Do your online friends make you pay? A randomized field experiment on peer influence in online social networks. Management Science 2015, 61: 19021920.

Creates a randomized control trial on Facebook that avoids subject self-selection and observation bias.

* Bi, S Liu, Z Usman, K.: The influence of online information on investing decisions of reward-based crowdfunding. Journal of Business Research, 2017, 71: 10-18.

Examines how online information influences investor decisions using a large dataset from a Chinese crowdfunding platform.

Changwony, FK, Campbell, K Tabner, IT: Social engagement and stock market participation. Review of Finance 2015, 19: 317-366.

Chiu, $\mathrm{P}$, Teoh, SH Tian, F: Board interlocks and earnings management contagion. The Accounting Review 2012, 88: 915-944.

Einav, L Levin J: The data revolution and economic analysis. Innovation Policy and the Economy 2014, 14: 1-24.

Engelberg, J Gao, P Parsons, CA: Friends with money. Journal of Financial Economics 2012, 103: $169-188$.

Han, B Yang, L: Social networks, information acquisition, and asset prices. Management Science 2013, 59: 1444-1457.

Hong, H, Kubik, JD Stein, JC: Social interaction and stock-market participation. Journal of Finance 2004, 59: 137-163.

Ivković, Z, Weisbenner, SJ: Information diffusion effects in individual investors' common stock purchases: Covet thy neighbors' investment choices. Review of Financial Studies 2007, 20: $1327-1357$. 
Iyer, R Khwaja, AI Luttmer, EFP Shue, K: Screening peers softly: Inferring the quality of small borrowers. Management Science 2015, 62: 1554-1557

Javakhadze, D Ferris, SP French, DW: Social capital, investments, and external financing. Journal of Corporate Finance 2016, 37: 38-55.

Knüpfer, S Rantapuska, E Sarvimäki, M: Formative experiences and portfolio choice: Evidence from the Finnish great depression. The Journal of Finance 2017, 72: 133-166.

Li, E Martin, JS: Capital formation and financial intermediation: The role of entrepreneur reputation formation. Journal of Corporate Finance 2016: Forthcoming.

Lin, M Prabhala, NP Viswanathan, S: Judging borrowers by the company they keep: Friendship networks and information asymmetry in online peer-to-peer lending. Management Science 2013, 59: 17-35.

Manski, CF: Identification problems in the social sciences. Harvard University Press: Cambridge, MA; 1995.

Michels, J: Do unverifiable disclosures matter? Evidence from peer-to-peer lending, The Accounting Review 2012, 87: 1385-1413.

Miller, MM: Social networks and personal bankruptcy. Journal of Empirical Legal Studies 2015, 12: 289-310.

Mollick, E Nanda, R: Wisdom or madness? Comparing crowds with expert evaluation in funding the arts. Management Science 2016, 62: 1533-1553.

* Rau, PR, Law, trust, and the development of crowdfunding. Unpublished working paper, University of Cambridge, 2017.

One of the first large-scale country-level studies on the development of crowdfunding across the world

Rau, PR Wardrop R: Are all investors identical in explaining the local bias effect?

Unpublished working paper, University of Cambridge, 2017.

Varian, HR: Big data: New tricks for econometrics. Journal of Economic Perspectives 2014, 28: 3-28.

Zhang, J Liu, P: Rational herding in microloan markets, Management Science 2012, 58: 892912. 